\title{
Exploring Uniting Reformed Church of South Africa African pastors' well-being, calling and healing: An interactive qualitative analysis
}

\begin{tabular}{|c|c|}
\hline \multicolumn{2}{|c|}{$\begin{array}{l}\text { Authors: } \\
\text { Elizabeth C. Rudolph }{ }^{1} \text { (1) } \\
\text { Christina Landman }\end{array}$} \\
\hline \multicolumn{2}{|c|}{$\begin{array}{l}\text { Affiliations: } \\
\text { }{ }^{2} \text { Department of Human } \\
\text { Resource Management, } \\
\text { College of Economic and } \\
\text { Management Science, } \\
\text { University of South Africa, } \\
\text { Pretoria, South Africa }\end{array}$} \\
\hline \multicolumn{2}{|c|}{$\begin{array}{l}{ }^{2} \text { Research Institute for } \\
\text { Theology and Religion, } \\
\text { University of South Africa, } \\
\text { Pretoria, South Africa }\end{array}$} \\
\hline \multicolumn{2}{|c|}{$\begin{array}{l}\text { Corresponding author: } \\
\text { Elizabeth Rudolph, } \\
\text { rudolec@unisa.ac.za }\end{array}$} \\
\hline $\begin{array}{l}\text { Dates: } \\
\text { Received: } 03 \mathrm{~N} \\
\text { Accepted: } 05 \mathrm{~S} \\
\text { Published: } 11\end{array}$ & $\begin{array}{l}\text { May } 2019 \\
\text { Sept. } 2019 \\
\text { Dec. } 2019\end{array}$ \\
\hline \multicolumn{2}{|c|}{$\begin{array}{l}\text { How to cite this article: } \\
\text { Rudolph, E.C. \& Landman, C., } \\
\text { 2019, 'Exploring Uniting } \\
\text { Reformed Church of South } \\
\text { Africa African pastors' } \\
\text { well-being, calling and } \\
\text { healing: An interactive } \\
\text { qualitative analysis', HTS } \\
\text { Teologiese Studies/Theological } \\
\text { Studies } 75(4) \text {, a5539. https:// } \\
\text { doi.org/10.4102/hts. } \\
\text { v75i4.5539 }\end{array}$} \\
\hline \multicolumn{2}{|c|}{$\begin{array}{l}\text { Copyright: } \\
\text { (C) 2019. The Authors. } \\
\text { Licensee: AOSIS. This work } \\
\text { is licensed under the } \\
\text { Creative Commons } \\
\text { Attribution License. }\end{array}$} \\
\hline \multicolumn{2}{|l|}{ Read online: } \\
\hline 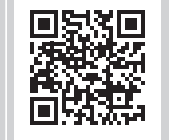 & $\begin{array}{l}\text { Scan this QR } \\
\text { code with your } \\
\text { smart phone or } \\
\text { mobile device } \\
\text { to read online. }\end{array}$ \\
\hline
\end{tabular}

The caregiving focus of churches is on congregational members and communities, and often the well-being of the pastor is neglected. Emanating from the medical health model, the focus of caregiving in the past was on ill-being. Positive psychology introduces another focus in caregiving, which is well-being. This article reports that three primary drivers emerged during an interactive qualitative analysis (IQA) focus group activity with four African pastors from the Uniting Reformed Church of South Africa (URCSA). These drivers are the calling of the pastor, servant leadership and pastoral reflection. The first aim of this article is to describe the driving factors that were identified by the focus group as important in terms of their wellbeing in the ministry. The second aim is to describe how the construct 'Calling' has contributed to an identity of discipleship over and above diaconal healing for pastors.

Keywords: well-being; calling; healing; interactive qualitative analysis; discipleship; diaconal healing.

\section{Introduction}

Ministry, like life, can be stranger than fiction. ... I cannot promise that you will make the right decisions or take the right actions. Good ministry is never merely a matter of solving problems; it is a mystery to be ventured and explored. But we can journey into this mystery with knowledge and skills that help us find our way as we move along. Or we can stand where I did, on a porch with only my gut to tell me whether I should knock again or leave. (Osmer 2008:3)

Globally and nationally, constant change is contemporary, and various external factors of a political, economic, social and technological nature cause pressure within the workplace (Cooke \& Nel 2010). As a result, Dreyer (2016) argues that 'strategic decision-making' became a well-known term in the church environment to keep up with change. The caregiving focus of churches on congregational members and communities at a strategic and operational level is noteworthy, but often the well-being of pastors is neglected, and the focus is on ill-being rather than on well-being (Cooke 2007, 2008; Nel 2005; Tomic, Tomic \& Evers 2004). Nel (2009) indicates that the Centre for Contextual Ministry allows pastors and leaders from almost all denominations and other independent religious communities to attend various theological courses in order to build capacity within the church. Nel also notes that an advisory committee at the University of Pretoria realised the need for training of community and church leaders, as many of the students are not in full-time ministry. Students with teaching experience who were successful in the advanced courses were tasked to present a basic ministry course in rural and urban areas across South Africa and the continent (Rudolph 2019:15).

In general, work plays a fundamental role in people's lives (Kaplan, DeShon \& Tetrick 2017), and pastors are not excluded (Buys \& Rothmann 2010). It would seem that capacity building is still a constraining element in the URCSA (Sixth General Synod of URCSA 2012). Consequently, the URCSA has taken the initiative to improve leadership capacity by providing in-service training, encouraging personnel to undertake academic studies and rewarding those who participate and succeed (in other words continuous professional development). However, within the URCSA, no formal/informal mentoring and/or coaching programme and/or continuous professional development processes have yet been developed and this aspect remains a work in progress (Landman 2015). Consequently, the URCSA has not yet been able to describe the extent to which pastors are able to optimise their well-being in order to remain engaged in their calling. Then again, with reference to the quote from Osmer (2008) above, opportunities for capacity building 
do not need to result in feeling that the ministry is stranger than fiction or working from gut feelings on how to make decisions and/or to act in specific situations.

The aim of this article is to state the important elements that drive the participants towards well-being in the ministry, and how the construct 'Calling' contributes to the identity of discipleship over and above diaconal healing for pastors. This article is positioned in the growing body of knowledge related to the well-being of pastors in the ministry, as part of findings in a study towards the degree of Doctor of Philosophy (Psychology) by Rudolph (2019). The title of the thesis is 'A coaching model to care for the well-being of pastors: A multidisciplinary perspective'. It is registered in the Department of Industrial and Organisational Psychology at the University of South Africa.

Firstly, a brief literature background is given on the constructs 'well-being', 'Calling' and 'Healing'. A discussion of the research methodology used in the doctoral research follows. Finally, recommendations are made on how pastors could be cared for in the ministry. These recommendations on how to care for pastors are an important element of a research process because the findings of a thesis easily do not reach those people who can act on them (Flynn \& Kramer 2019:151). Hence, we hope that the results, findings and recommendations of this study would benefit other scholars, educators, community members, church leaders and peers of the URCSA pastors in the various Christian denominations within South Africa.

\section{Well-being}

According to Goss, Cuddihy and Michaud-Tomson (2010):

Wellness is a state of being in which a person's awareness, understanding and active decision-making capacity are aligned with their values and aspirations. A Wellness lifestyle is the commitment and approach adopted by an individual aiming to reach their highest potential. The outcome of a Wellness lifestyle is a capacity to contribute in positive and meaningful ways to one's community, society and the welfare of the earth. An individual who adopts a Wellness lifestyle aims to balance the multiple dimensions of their health and well-being in concert with their environment. On a continuum between low-level Wellness and high-level Wellness, individuals continually move between various states of physical, psychological and spiritual harmony and vary in their capacity to reach aspirations and goals. (pp. 5-6)

Within the South African context, psychological studies related to the ministry as a career include investigations and explorations of employee ill-being in terms of stress, burnout and engagement (Barnard \& Curry 2012; Berry et al. 2012; Buys \& Rothman 2010). In the past, in the medical health model, the focus in caregiving was on ill-being within psychology (Travis 2004, Travis \& Callander 2013, Travis \& Ryan 2004). In contrast to ill-being, positive psychology introduces well-being as a fundamental element of managing human resources in organisations globally; this is consistent with the trend in contemporary research (Donaldson, Csikszentmihalyi \& Nakamura 2011; Kaplan et al. 2017; Seligman 2011; Seligman, Parks \& Steen 2004; Wong 2004, 2011).
Every organisation is challenged to maintain the individual well-being of its members, which has consequences for both the organisation and the economy (Kirsten, Van Der Walt \& Viljoen 2009; Louw 2010; 2014a, b; Seligman 2011). Huppert and So (2011) state that scholars have become more interested in the benefits that high levels of well-being have for individuals and society. Churches act as non-profit organisations with the vision of caring and contributing to community building, whilst focusing on the broader context of spirituality and existential practices (Ganzevoort \& Roeland 2014). Spirituality according to Dreyer (2011) is a comprehensive life orientation that determines one's identity and that includes one's entire human existence as an authentic person in God's presence. Intrigued by Maria Aránzu Aguado's call for a growing awareness about spirituality as a basic pillar in the journey towards unity, Plaatjies Van Huffel (2017:9) summaries that in future, spirituality will be one of the key elements to develop a life-centred understanding of the oikoumene that embraces all of God's creation.

Non-profit organisations such as churches are not exempt from the obligation to create a safe and healthy workplace for their employees. In fact, professionals who choose the ministry as a career experience unique work pressures, such as preparing and delivering a sermon, pastoral care, trauma and bereavement counselling, administrative, managerial and organisational tasks, catechism and meetings (Buys \& Rothman 2010; Cilliers 2005; Cooke 2007, 2008, 2011; Ganzevoort \& Roeland 2014).

Pastors are well-known for their personal well-being and seem in general to be satisfied with their family lives, but at times they have difficulty managing their work-life balance and are at times challenged by their roles and time management within the ministry (Berry et al. 2012; Rudolph \& Barnard 2015; Schoeman 2012). Buys and Rothman (2010) argue that if pastors within the Reformed Church have more job resources, they may experience work-role psychosocial flourishing as part of their calling. The self-determination theory (SDT) posits that intrinsic motivation enhances three psychological needs that improve well-being within the workplace, namely personal autonomy, competence and connectedness (Deci \& Ryan 2008).

\section{Calling}

Some researchers view the construct 'Calling' from a religious perspective as a summon, and the secular trend is also conceptualised in terms of the construct 'vocation', as defined by Dik and Duffy (2009):

A calling is a transcendent summons, experienced as originating beyond the self, to approach a particular life role in a manner oriented toward demonstrating or deriving a sense of purpose or meaningfulness and that holds other-oriented values and goals as primary sources of motivation. A vocation is an approach to a particular life role that is oriented toward demonstrating or deriving a sense of purpose or meaningfulness and that holds other-oriented values and goals as primary sources of motivation. (pp. 427-428) 
Work forms a central part of life and the choice thereof depends on whether employees experience their job as a calling or view it as a feeling for a calling or living a calling in a particular career (Duffy et al. 2018).

Psychologists offer a service to guide clients on the career options they may pursue, and psychometric assessments indicate the fields of interest, level of aptitude and personality type (Bergh 2011) that may require a spiritual dimension. Individuals' interest in, and motivation to choose, a specific career or vocation do not necessarily follow from an external or internal calling.

Spirituality becomes a more prominent construct in the world of business and is one way to explore individuals' core beliefs and preferences, which shape the way they make sense of their work and lives (Conway et al. 2015; Coyle \& Lochner 2011; Fourie 2010; Fourie \& Van Den Berg 2007; Koen, Van Eeden \& Rothman 2012; Marques, Lopez \& Mitchell 2013). Some people do not opt for a career based on their calling because of their situation and the realities of a turbulent changing world, which force people to focus more on finding a job for the sake of survival, job security and providing for their families (Dik \& Duffy 2009).

Die probleem is dus waarskynlik nie die rolle en verwagtings nie. Die eintlike probleem is dat ons op ons eie probeer groei - en dan in ons blindekolle verdwaal. Ons skuld dit aan onsself, aan die Here - en natuurlik aan gemeentes en die wêreld - om iets hieraan te doen. [The problem is probably not the roles and expectations. The real problem is that we try to grow on our own - and get lost in our blind spots. We owe it to ourselves, to God - and of course to the congregation and the world - to do something about this.] (Marais 2012:2 [authors own italics])

With reference to the above quote by the South African theologian Marais (2012), it is clear that Marais calls upon pastors to grow collectively with others and not to be blinded by the self-deception that they can grow by themselves.

Tshaka (2014:9) creates a dialogue about a deeply entrenched race question that includes issues of culture and African worldviews. Then again, Tshaka acknowledges that the Christian faith is seen to be flourishing in South Africa. As a result, the authors of this manuscript are cognisant of the debates of African or Western views linked to the reformed traditions as argued by Tshaka (2014). Nevertheless, within the disciplines of human resource management and/or industrial and organisational psychology, pastors find themselves in a world of continuous change, and one way to grow and adapt to such change is to create an interactive learning environment (Guest 2017) to breathe (live) their calling for all.

\section{Healing}

Meyers and Sweeney (2007) explain that the roots of wellness go back over 2000 years. They refer to the perceptions of the daughters of the Ancient Greek god of healing. Panacea, the first daughter, was believed to offer healing for existing illnesses and Hygeia, the second daughter, endorsed ongoing learning to develop positive ways of living to prevent illness.
Professionals need to be mindful about caring for healthy people but should also acknowledge the wounds of the distressed (Peterson 2006). Peterson's approach to healing these wounds reminds me of Jung's description (based on Greek mythology) of the relationship between professionals and their clients, where the effective healer is a 'wounded healer' (Jung 1961, cited in Nolte \& Dreyer 2010:3): 'The doctor is effective only when he himself is affected. Only the "wounded physician" heals. But when the doctor wears his personality like a coat of armour, he has no effect'.

Hence, most professionals aim to care for those who have a problem or who are ill (Louw 2014a). Those in distress want to heal their wounds, and others carry scars from their healed wounds. Nevertheless, most people are healthy most of the time and wish to live fulfilled lives and to function optimally (Nolte \& Dreyer 2010; Peterson 2006). In this article, the construct 'healing' is used in relation to the idea of Wessels and Müller (2013) that people interpret meaningful experiences as they interact within their networks (work-life).

Therefore, human beings are inextricably linked to the greater network of life; organisations are 'living' social systems made complex by continuous change in employee and organisational needs (Bergh 2011). The church is a social system that serves communities but challenges its own purpose, as summarised by Niemandt (2016).

Niemandt argues that the church tends to focus more on secular prosperity gospels, consumerism and individualism than discipleship to rediscover joy.

The current challenges of a changing world imply a radical discipleship of a life together (Bonhoeffer 1979; Nel \& Scholtz 2016; Niemandt 2015, 2016). The system of the church, involving individual employees, church councils, presbyteries and synods, combines with a vision of caring and contributing to community building whilst focusing on the broader context of spirituality and existential practices (Bonhoeffer 1979; Cooke 2007, 2008, 2011; Ganzevoort \& Roeland 2014; Nel \& Scholtz 2016; Niemandt 2016; Osmer 2008).

African churches practise their calling as a service to others in three ways: caring for others with a focus on healing, referred to as diaconal healing (healing through food packages, hospices and other forms of community service); faith healing (healing by prayer and the laying on of hands); and ritual healing (according to traditional African culture, which includes traditional healers, interpreting dreams, and singing hymns) (Landman 2007, 2012, 2015; Morekwa 2004). In the URCSA, diaconal healing reflects the compassionate orientation the church adopts to healing through the behavioural characteristics of servant leadership (such as empathy, compassion, altruistic calling, listening and healing) to manage followers' turmoil (Greenleaf 2016; Jit, Sharma \& Kawatra 2017).

As a conceptual conclusion related to the brief information regarding well-being, calling and healing, within theology, 
there is an alternative dialogue to that of the secular prosperity gospels, consumerism and individualism as part of people's calling. Nel (2017) says that the term 'Calling' reminds humankind of a divine calling 'because' of God as the acting 'Actor' of the church. A radical discipleship of koinonia does not require an autocratic rhetorical style to teach, monitor and enforce religious beliefs to one another or members of the congregation, but rather focuses on emotional, psychological and social well-being (Janse Van Rensburg, Rothmann \& Diedericks 2017; Rothmann 2013; Seligman 2011). Biblically, such an approach to a radical discipleship of koinonia is evident in Exodus 18:1-27. Moses' father-in-law, Jethro, advised him to serve the people by finding strength in the spiritual gifts of the people themselves (i.e. the congregation). Jethro advised Moses to create a structure that nurtured his own health, but more importantly that of the people that he led, by picking potential leaders, training them and empowering them (NIV Leadership Bible).

Hence, the URCSA focus group mentioned important themes related to the care of their well-being in the ministry and how the construct 'Calling' contributes to the missional identity of discipleship to help professionals in pastoral care over and above diaconal healing for pastors.

\section{Research methodology}

The research methodology is an IQA research design that provides a concurrent method for data gathering and analysis of lived experiences, as reflected by constituents with commonalities related to the phenomena under investigation (Albertyn, Van Coller-Peter \& Morrison 2017, 2018). Following Northcutt and McCoy (2004), the main steps in an IQA research design are (1) identifying an issue statement, (2) identifying and selecting constituencies and (3) concurrent data gathering and analysis.

\section{Identifying an issue statement}

The issue statement in this study follows from the doctoral thesis by Rudolph (2019). The issue statement could be seen differently by different constituencies in one group and is therefore a simple way to determine whether there is variation according to the lived experiences of constituents (Albertyn 2016; Northcutt \& McCoy 2004; Robertson 2015; Schreuders-Van Den Bergh 2013). Therefore, in the focus group session, the issue statement was projected onto a whiteboard to make it more visible, and the focus group was asked to speak about the topic: 'The subjective well-being of the pastor: Towards a multidisciplinary coaching model for helping professionals in pastoral care'.

The issue statement forms part of the introductory phase and of identifying and selecting constituencies.

\section{Identifying and selecting constituencies}

Four participants were recruited using purposive sampling by contacting registered pastors in the Northern Synod of the
URCSA (whose names appeared in the yearbook of 2014 as registered pastors). Participants were invited to participate through telephonic and email communications. A document was attached to the email relating to ethical research, such as the participant information sheet and the consent form to participate in qualitative research. An ethics certificate was obtained from the Department of Industrial and Organisational Psychology at the University of South Africa before the research process commenced. To ensure the confidentiality of participants' personal information, pseudonyms were used, and all necessary precautions were taken to minimise any personal identifiers of the participants.

\section{Concurrent data gathering and analysis}

Interactive qualitative analysis enables researchers to create a hermeneutical understanding of complex systems, of which constituents are the key authors, to construct and describe codes (called sub-affinities) and themes (called affinities) in two ways: focus groups and interviews (Northcutt \& McCoy 2004). Interactive qualitative analysis is an inclusive methodology because it enables researchers to direct the collection and analysis of qualitative data based on the four phases of the IQA research process, namely the research design, the focus group(s), the interview(s) and the report (Albertyn 2016; Albertyn, Van Coller-Peter \& Morrison 2017, 2018; Northcutt \& McCoy 2004; Robertson 2015; SchreudersVan Den Berg 2013). This article reports on the results of the focus group activity. Because of data saturation, only focus groups were used in the initial research study by Rudolph (2019) to gather the data in this study.

Affinity production, silent brainstorming and a warm-up exercise enabled the participants in the focus group to focus on the issue statement and to briefly give the background to their well-being experiences in the ministry.

This was done on notecards and is a silent process, and participants were not allowed to communicate with one another. Then, the participants posted their notecards randomly on a whiteboard. Only then did the facilitator (the main author of this article) refer to each notecard and gave participants an opportunity to share their personal stories related to their well-being in the ministry. An interactive dialogue between participants resulted in the development of sub-affinities and categorising and crafting affinities. Each sub-affinity and affinity included individual stories.

The dialogue between participants resulted in the development of two processes, called theoretical coding (ART) by Northcutt and McCoy (2004), and the development of an interrelated diagram (IRD). The ART and the IRD were constructed by the facilitator. Lastly, the facilitator followed Northcutt and McCoy (2004)'s process to create an uncluttered systems influence diagram (SID) or mindmap. In the words of Northcutt and McCoy (2004:176), a SID is 'a set of qualitative structural equations or ... a path diagram ... in that recursion or feedback loops are allowed'. 
The interaction between participants in the focus group was tape-recorded with the consent of the participants and the facilitator personally transcribed the recorded data afterwards. During the focus group activity, the facilitator made brief notes about the interactions among the participants, which were used as the tape-recordings were transcribed into a Word document. As shown in Table 1, the URCSA group discussed five affinities linked with various sub-affinities.

Robertson (2015) views the SIDs of IQA data as visual realities and building blocks based on the affinity pair relations, which constitute a plot of the drivers, circulars/pivots, and

TABLE 1: Identified affinities and sub-affinities.

\begin{tabular}{ll}
\hline Affinity & Sub-affinities \\
\hline Calling & $\begin{array}{l}\text { Journey, before studying theology } \\
\text { Conflict management }\end{array}$ \\
$\begin{array}{l}\text { Management, conflict, challenged, sharing ideas, } \\
\text { disagreement } \\
\text { Success }\end{array}$ & $\begin{array}{l}\text { Change, build, help, respect, strategic planning, love, } \\
\text { relation }\end{array}$ \\
Servant leadership & $\begin{array}{l}\text { Minister, preaching, obedience, personality, passion, singing } \\
\text { hymns, study }\end{array}$ \\
Family building & Home ministers, home congregation, morals \\
\hline
\end{tabular}

Source: Adapted from Rudolph, E.C., 2019, 'A coaching model to care for the well-being of pastors: A multidisciplinary perspective', Doctoral dissertation, University of South Africa, viewed from https://uir.unisa.ac.za/handle/10500/25671; Rudolph, E.C. \& Barnard, A., 2015, 'A voice in the dirt: African pastors on being well', poster presentation at the European Conference of Psychology (ECP), Milan, Italy, 7-10 July. outcomes evident in the final uncluttered SID of the URCSA focus group. Hence, the rigorous IQA protocol enabled the researcher to create the uncluttered SID as shown in Figure 1. This synthesised SID illustrates the affinities and their interrelationships that represent pastors' lived experiences of well-being as voiced in a turbulent South African work context, referred to as 'dirt' by Rudolph and Barnard (2015). The focus group identified three driving factors (called primary drivers) that they saw as important to their wellbeing in the ministry: 'reflection', 'servant leadership' and 'calling'. They also indicated how the construct 'Calling' contributed to a discipleship identity of healing over and above diaconal healing for pastors.

With reference to Table 1 and Figure 1, more in-depth information related to the three driving factors follows.

\section{Research findings and discussion}

Aligned with the aim of this article, the three driving factors (see Figure 1) are now described. Verbatim evidence of what individual participants said relating to their well-being is given. Next, information about the other affinities found as pivotal (namely The End, Journey [during career], Family

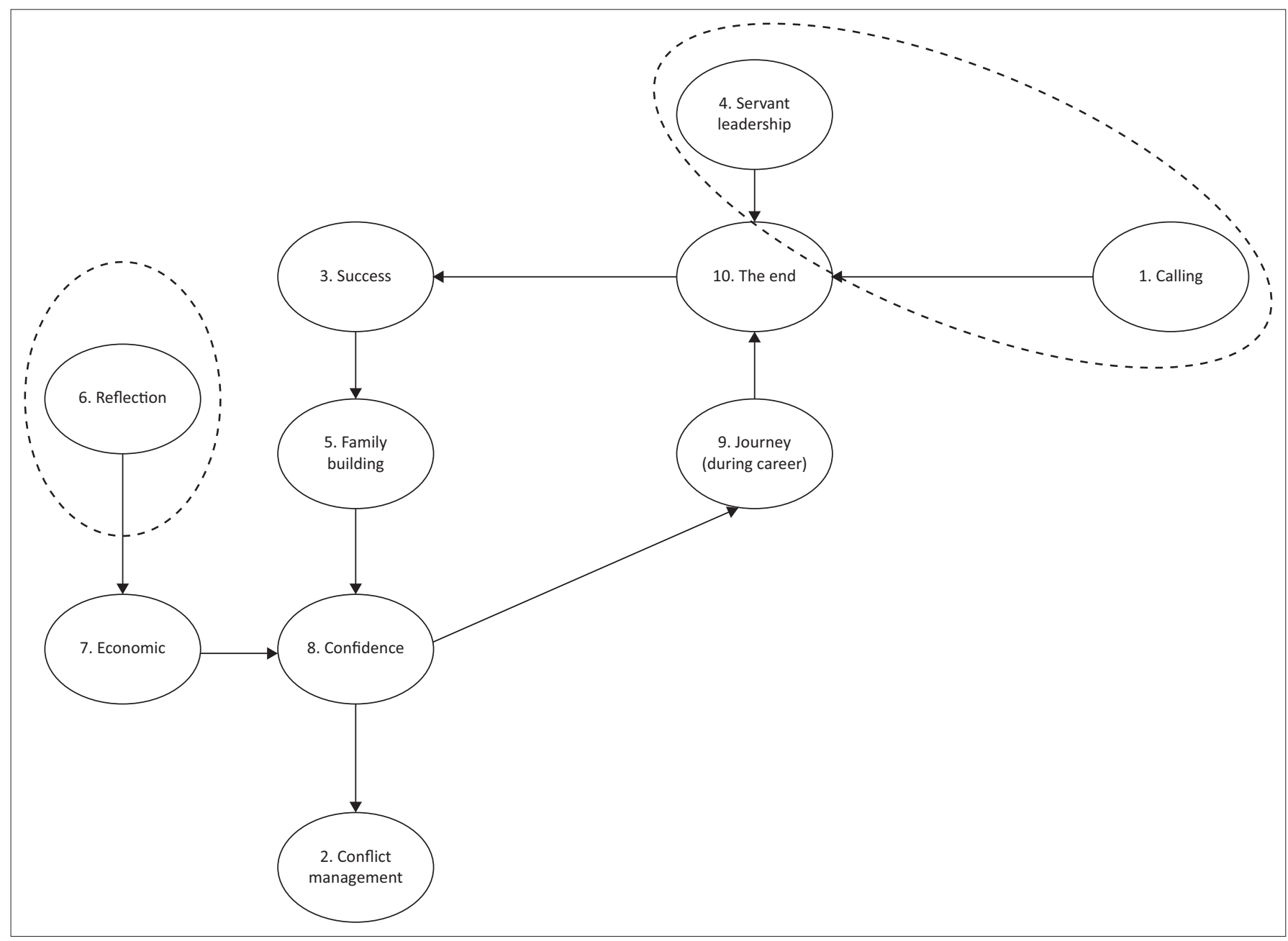

Source: Adapted from Rudolph, E.C., 2019, 'A coaching model to care for the well-being of pastors: A multidisciplinary perspective', Doctoral dissertation, University of South Africa, viewed from https://uir.unisa.ac.za/handle/10500/25671

FIGURE 1: Focus group's uncluttered systems influence diagram. 
building, Confidence, Economic) is added. Lastly, the primary outcome, called 'Economic', is discussed as it has an implication for how the construct 'Calling' contributes to a discipleship identity of healing over and above diaconal healing for pastors.

\section{Calling}

The participants in the focus group placed the sub-affinities Journey, Before studying and Theology in one category and labelled the affinity 'Calling'. Reverend Moses explained how as a young child his decision to accept God's calling was influenced by other believers:

Reverend Moses: I was going to the doctor with my mother and I was young then. I went into surgery. [The doctor said to my mother:] ... 'this young boy, the way he behaves, his personality, I think the right profession is to become a pastor.' It started there ... [In my] mind that time ... I thought about [the words of the doctor] and took this decision. (Rudolph 2019:195)

Reacting to the above example, the participants agreed that the affinity 'Calling' is a reflection on a journey to cope with their well-being in the ministry. For example, Revd. Johannes explained that during the apartheid era in South Africa, he accepted his calling:

Reverend Johannes: I was a student at the University X. On 14 February, I was arrested and went to jail. When I was there, I dreamt of a cross. When I was arrested, there was no charge for my arrest. After six months, I was released from prison. I went back home and began to work at Company Y. I ... decided to complete school. I decided to complete another course that was related to things of mining. I did not finish the course, I thought of going back to university. I decided to take the ministry, in this course of Theology. [Before my arrest] at the time, I was young, at the age of 11 or 12, I dreamt that my grandfather came to me and gave me a stick and a bible. (Rudolph 2019:195)

The theme 'Calling' encapsulates a deeper understanding of a spiritual journey to become servants like Jesus Christ (Rudolph 2019:195). This spiritual journey, according to Rudolph's understanding of the participants' experiences of their well-being in the ministry, begins with God and God is the One who takes the initiative by grace to call each participant to be disciples (servants) of Jesus Christ, unique to their own circumstances (i.e. through dreams or as a child through others). Finally, if one chooses a calling on an intrapersonal level but chooses to live one's calling on a fulltime basis like the participants in this study, it will probably require making sacrifices to enhance the lives of others (i.e. congregation, community, family and friends).

\section{Servant leadership}

The nature of servanthood became evident in the stories that the participants shared with one another during the focus group. The participants used sub-affinities such as Minister, Preaching, Obedience, Personality and so on to explain how the affinity 'Servant leadership' forms part of their employee well-being in the ministry (Rudolph 2019:200). The participants attached a meaning to this affinity as their belief in God and their passion for sustaining their calling through continuing professional development (studying). Secondly, the participants described the affinity as a way of preaching the Word of God using contemporary language (theology). Lastly, participants described this affinity as sacrificing oneself to serve others and obey God's calling, as reflected in the words of Revd. Johannes:

Reverend Johannes: To be a servant and a true servant allows one to accept the calling (I am called). [...] Proclaiming the Word is not the only goal but also doing things in a practical way, visiting the sick. (Rudolph 2019:200)

Revd. Johannes has journeyed with God since childhood - a journey that started with a dream. In jail, Revd. Johannes had a second dream. His experiences in jail followed a period in his life in which he felt out of step with the laws of South Africa, but he had a calling from God. The affinity 'Servant leadership' was ranked as a primary driver by the participants. To remain true to their faith, they demonstrated a desire to build on their relationship with God by reflecting and learning continuously about their calling and their standing as church office-bearers.

\section{Reflection}

The participants also referred to a learning process in terms of the following affinities. The first affinity is the one that the group called Reflection (Rudolph 2019:217). The participants regarded this affinity in the ministry as a primary driver of employee well-being. In this affinity, the participants emphasised reflecting continuously on their dignity, faith and spiritual beliefs as office-bearers of the church. For example, Revd. Moses said in this regard:

Reverend Moses: As part of my personality and my calling, I reflected on my spirituality and really think deeper about being a pastor in the world. It really changed my life. (Rudolph 2019:204)

The participants identified another affinity linked to the process of learning, called Journey (during the career). The researcher probed this affinity further to determine whether the participants wished to merge the affinity 'Reflection' with that of 'Journey (during the career)', but they disagreed. The affinity that the participants identified as Journey (during the career) only had one sub-affinity, namely, Recall, based on a brief comment made by Revd. Petrus, yet the participants insisted on differentiating the two affinities:

Reverend Petrus: To recall the life one experience. (Rudolph 2019:205)

The participants regarded the affinity 'Reflection' as a primary driver of experiences related to employee wellbeing, as it is a reflection on the past, while Journey (during career) was regarded as a circular or pivot of employee's experiences related to well-being, which the participants felt was a reflection on the present. The connotations of the above-mentioned affinities in each focus group demonstrate that the process of learning must begin with a clear 
understanding of oneself and one's own development if one is to make sense of God's calling. In addition to the awareness of learning that evolved in this study, participants felt a need to set goals for themselves in the ministry to increase their maturity on both an intrapersonal and interrelationship level to serve others, as God requires. Consequently, the participants revealed that they took ownership of their learning in order to learn about themselves on an individual level, and to reflect continuously on the way their personal, spiritual and emotional wellbeing increases in order to serve others (linked with the affinity 'Confidence' in Figure 1).

Reverend Mathew shared the temptation he experienced to appropriate the financial contributions of the congregations during his practical year (see the affinity 'Economic' in Figure 1). This temptation to misuse organisational funds could be described as an ethical dilemma and required higher-order critical reasoning, thinking and self-reflection to make wise decisions in this regard. According to his religious beliefs and values, Revd. Mathew's reasoning showed a level of autonomy linked to his psychological well-being in setting acceptable standards internally and following his religious values in his work:

Reverend Mathew: I was asked to bank money every Monday and always money was coming short, and hard to pay it and other side I was not getting payment. I have changed the method of contribution and teach congregants about finance. (Rudolph 2019:211)

Reverend Mathew argued that before you serve others, you should look inward and reflect on the self. He argued the importance of sacrificing one's own interests and obeying God's calling to serve others (see the affinity 'Servant leadership' in Figure 1):

Reverend Mathew: Do self-reflection before you address the people. (Rudolph 2019:218)

The complexity of the discomfort that the participants experience daily at work depends on the demands linked to secular issues (i.e. economic, political and social) that are beyond the control of the participants and/or congregations. According to the participants, these demands result in unexpected changes. Thus, the affinity 'Conflict management' helps the participants to mature and develop over the years of their ministry. The participants also presented a positive affirmation of their personal worth, strengths, weaknesses and shortcomings through continuous reflection because they develop and mature through their experiences of conflict in the ministry. The participants attempted to demonstrate that they were realistic about their present and past experiences of well-being.

Hence, their ability to reflect continuously on issues beyond the control of the participants and/or the congregations requires them to develop management skills, which did not form part of their theological and pastoral training (Beek 2010). Additionally, in interacting with their physical and social environment, they develop and apply an array of complex cognitive behavioural skills (Cilliers 2011). On an intrapersonal level, multiple feelings fall within the emotional well-being dimension that forms part of the participants' selfassessment of the emotional impact on their satisfaction level regarding life and work, which enables them to become more self-directed in the ministry (Cilliers 2011; Rothmann 2013). Furthermore, maintaining a positive attitude to learning and developing enables participants to flourish in their work. Participants also are enabled to evaluate their situation, reflect on their past experiences and find tactics from their past to deal with difficult situations; they also learn to apply resources within the ministry wisely in order to perform well in the job and enhance their satisfaction level.

The participants embrace situational influences and disruptive occurrences in their daily functioning and wellbeing as developmental moments in their career. The participants also choose how to deal with the difficulties of the ministry. In being thus open to constant reflection and learning about good and bad, they are enabled to create an in-depth understanding of the self and others to act with the required human dignity in the ministry. Pastors can become aware of their maximum potential at work and enrich their work and personal life to contribute practically to the development of a sustained network of people management in the Church context.

Continuous reflection on one's own behaviour during a pastoral session, the emotional turmoil resulting from various tasks and the different seasons of the ministry could result in an 'end' to wrongdoing or unethical thoughts. Ongoing reflection on one's own behaviour could also be the start of creating human capital (people) in the organisation of God and seeing death as the beginning of eternity (see the affinity 'The End' in Figure 1).

On a personal level, the participants in this study demonstrated a sense of responsibility and accountability to live out their altruistic calling, no matter how difficult the tasks involved in their ministry. Additionally, the participants shared a need to remain up to date within the contemporary, changing world through ongoing learning, bearing in mind what is done on the job and reflecting on what they thought, felt and did in the different pastoral tasks. Hence, continuous reflection is applicable not only to the pastors' development but also to the congregation, as recommended by the participants in this study. The participants called upon congregational members and colleagues to reconsider their ethical attitudes (see 'Family Building' in Figure 1).

All who attend services should feel welcome and be granted the necessary dignity, privacy and honesty. As the human capital of God, koinonia is important for the optimal functioning of congregational members in working together to ' $[b] \mathrm{e}$ the salt of the earth and to be the light of God (Mt 5:13-16, NIV)'. 
In this article the factors driving well-being in the ministry encapsulate an important construct, namely 'Calling'. Calling contributes to an identity of discipleship over and above diaconal healing for pastors. The anticipated contribution of the preliminary findings in this article links to the work of Duckworth, Steen and Seligman (2005) on well-being, positioned from a positive psychological disciplinary paradigm:

$[P]$ ersons who carry even the weightiest psychological burdens care about much more in their lives than just the relief of their suffering. Troubled persons want more satisfaction, contentment, and joy, not just less sadness and worry. They want to build their strengths, not just correct their weaknesses. And, they want lives imbued with meaning and purpose. These states do not come about automatically simply when suffering is removed. Furthermore, the fostering of positive emotion and the building of character may help - both directly and indirectly - to alleviate suffering and to undo its root causes. (p. 630)

From an African transformative receptive ecumenism theological disciplinary paradigm, Plaatjies Van Huffel (2017:12) calls upon scholars to take into consideration various ideologies (i.e. the world and contemporary) that are inclusive, empowering and life-giving in response to God's agenda in the world. With God's agenda in the world, Plaatjies Van Huffel calls upon scholars and specifically Africans to appreciate what can be learnt or received, with integrity from others, firstly. Secondly, Plaatjies Van Huffel argues that God's agenda is to accompany people in their struggle for justice and life. Lastly, Plaatjies Van Huffel envisions the unity of a whole humanity and creation.

From a practical theological disciplinary paradigm, according to Louw (2017:4) 'being functions' refers to responsibility (respondeo ergo sum) and is embodied and exemplified in the happenstances of life that represent a state of being and a state of mind. Secondly, Louw argues that 'being functions' is a qualitative term and is directly related to mindset, schema of interpretation, ethos and aptitude. Lastly, Louw argues that the being function in pastoral caregiving is fundamentally about the quality of a human soul (habitus).

The office of the pastor carries a weighty psychological and spiritual burden of its own; yet the pastor's soul or calling takes him or her on a journey to build and foster positive emotions and to build a character that serves others rather than themselves. Pastors' inner souls (as driven by their calling) act as indicators of the quality of their well-being that flourishes within the workplace.

\section{Conclusion and summary}

African churches practise their calling as a service to others in three ways of healing: diaconal (community service); faith (prayer and laying on of hands); and ritual (according to the traditional African culture that includes traditional healers, interpreting dreams and singing hymns) (Landman 2007, 2012, 2015; Morekwa 2004), yet the URCSA pastors in this study emphasised that their calling is situated in an identity of discipleship. As indicated earlier in the literature on the emphasis on diaconal healing, churches adopt a compassionate approach of servant leadership in their orientation to healing through the behavioural characteristics of servant leadership (such as empathy, compassion, altruistic calling, listening and healing) to manage followers' turmoil (Greenleaf 2016; Jit, Sharma \& Kawatra 2017). Yet, as a conceptual conclusion related to the brief information regarding well-being, calling and healing given in this article, within theology there is an alternative dialogue to that of the secular prosperity gospels, consumerism and individualism as part of people's calling. Nel (2017) remarks that the term 'Calling' reminds humankind of a divine calling 'because' of God as the acting 'Actor' of the church. A radical discipleship of koinonia does not require an autocratic rhetorical style to teach, monitor and enforce religious beliefs with one another or members of the congregation, but rather focuses on emotional, psychological and social well-being (Janse Van Rensburg et al. 2017; Rothmann 2013; Seligman 2011).

\section{Acknowledgements}

The authors acknowledge the inputs of Prof. A. Barnard as the main supervisor of E.C.R. in her PhD study (Industrial and Organisational Psychology). Some of the work in this article stems from E. C.R.'s thesis, entitled 'A coaching model to care for the well-being of pastors: A multidisciplinary perspective', presented in partial fulfilment for the degree of Doctor of Philosophy in Psychology at the University of South Africa in 2019.

\section{Competing interests}

The authors declare that they have no financial or personal relationship which may have inappropriately influenced them in writing this article.

\section{Authors' contributions}

E.C.R. (University of South Africa) is the main researcher as this article is a report on findings taken from the thesis towards the degree of PhD (Industrial and Organisational Psychology). C.L. (University of South Africa) mentored E.C.R. in the writing of the article.

\section{Ethical consideration}

This article followed all ethical standards for a research without direct contact with human or animal subjects.

\section{Funding information}

The authors declare that they have no financial or personal relationship which may have inappropriately influenced them in writing this article.

\section{Data availability statement}

Due to the sensitive nature of the questions asked in this study, participants were assured raw data would remain confidential and would not be shared. Pseudonyms were 
used to protect the privacy of the participants. Verbatim quotes could be accessed on the thesis towards the degree of PhD by Rudolph 2019 on the University of South Africa repository.

\section{Disclaimer}

The views and opinions expressed in this article are those of the authors and do not necessarily reflect the official policy or position of any affiliated agency of the authors.

\section{References}

Albertyn, R., 2016, 'Interactive qualitative analysis', ASEV Research and Development Consultants, presented at the University of South Africa, Pretoria, 27-28 September.

Albertyn, R.M., Van Coller-Peter, S. \& Morrison, J., 2017, 'Aligning student and supervisor's perspectives of research challenges', in M. Fourie-Malherbe, R.M. Albertyn, C. Aitchison \& E.M. Bitzer (eds.), Postgraduate supervision: Future foci for the knowledge society, pp. 171-188, Sun Media, Stellenbosch. https://doi. for the knowledge society, pp. 171
org/10.18820/9781928357223/10

Albertyn, R.M., Van Coller-Peter, S. \& Morrison, J., 2018, 'A multi-level researcher development framework to address contrasting views of student research challenges', South African Journal of Higher Education 32(1), 13-30. https://doi. org/10.20853/32-1-1639

Barnard, L.K. \& Curry, J.E., 2012, 'The relationship of clergy burnout to self-compassion and other personality dimensions', Pastoral Psychology 61(2), 149-163. https:// doi.org/10.1007/s11089-011-0377-0

Beek, A.M., 2010, 'A cross-cultural case for convergence in pastoral thinking and training', Pastoral Psychology 59(4), 471-481. https://doi.org/1001007/S11089009-0201-2

Bergh, Z., 2011, Introduction to work psychology, Oxford University Press, Cape Town.

Berry, A., Francis, L.J., Rolph, J. \& Rolph, P., 2012, 'Ministry and stress: Listening to Anglican clergy in Wales', Pastoral Psychology 61(2), 165-178. https://doi. org/10.1007/s11089-011-0388-x

Bonhoeffer, D., 1979, The cost of discipleship (Rev. ed.), Macmillan, New York.

Buys, C. \& Rothmann, S., 2010, 'Burnout and engagement of Reformed Church ministers', South African Journal of Industrial Psychology 36(1), 1-11.

Care, O.H. \& Louw, D.J., 2018, 'Wholeness in spiritual healing and helping: Towards a base anthropology for a pastoral hermeneutics', Proceedings of the 2nd Biennia South African conference on spirituality and healthcare, Cambridge Scholars Publishing, p. 16, viewed 02 May 2019, from https://books.google.co.za/books?h $|=e n \&| r=\& i d=b p 9 f D w A A Q B A J \& o i=f n d \& p g=P A 16 \& d q=l o u w+r e f e r s+t o+r e s p o n s i b i l$ ity+(respondeo+ergo+sum)\&ots=h31mlp-ISz\&sig=pk2VQ7-njBFbCdT85FsLxQjHV $9 \mathrm{~g} \# \mathrm{v}=$ onepage $\& \mathrm{q} \& \mathrm{f}=$ false.

Cilliers, F., 2005, A systems psycho-dynamic interpretation of coaching experiences, viewed 03 April 2019, from https://www.researchgate.net/publication/228591009 A SYSTEMS PSYCHO-DYNAMIC INTERPRETATION_OF_COACHING_EXPERIENCES.

Cilliers, F., 2011, 'Positive psychology leadership coaching experiences in a financial organisation', SA Journal of Industrial Psychology/SA Tydskrif vir Bedryfsielkunde 37(1), 1-14. https://doi.org/10.4102/sajip.v37i1.933

Conway, N., Clinton, M., Sturges, J. \& Budjanovcanin, A., 2015, 'Using selfdetermination theory to understand the relationship between calling enactment and daily well-being', Journal of Organizational Behavior 36(8), 1114-1131. https://doi.org/10.1002/job.2014

Cooke, F.T., 2007, Die gebruik van die pastor pastorum in die pastorale versorging van die predikante van die Nederduitse Gereformeerde Kerk. Ter vervulling van die vereistes vir die graad DD, Fakulteit Teologie, Universiteit van Pretoria, Pretoria.

Cooke, F.T., 2008, 'Pastor Pastorum in die pastorale versorging van die predikant', Practical Theology in South Africa $23(2), 22-43$, viewed 14 June 2016, from
https://repository.up.ac.za/dspace/bitstream/handle/2263/9987/Cooke_ https://repository.up.ac.za/dspace/bi
Pastor\% $0282008 \% 29$.pdf?sequence=1\&is.

Cooke, F.T., 2011, 'The pastor as model for peaceful existence', Verbum et Ecclesia 32(2), 1-6. https://doi.org/10.4102.ve.v32i2.500

Cooke, F.T. \& Nel, M., 2010, 'Die keuring van kandidate vir teologiese opleiding: Noodsaak en toepassing', HTS Teologiese Studies/Theological Studies 66(2), Art. \#828, 1-6. https://doi.org/10.4102/hts.v66i2.828

Coyle, A. \& Lochner, J., 2011, 'Religion, spirituality and therapeutic practice', The Psychologist 24(4), 264-266.

Deci, E.L. \& Ryan, R.M., 2008, 'Hedonia, eudaimonia, and well-being: An introduction', Journal of Happiness Studies 9, 1-11. https://doi.org/10.1007/ s10902-006-9018-1

Dik, B.J. \& Duffy, R.D., 2009, 'Calling and vocation at work: Definitions and prospects for research and practice', The Counselling Psychologist 37(3), 424-450. https:// doi.org/10.1177/0011000008316430

Donaldson, S.I., Csikszentmihalyi, M. \& Nakamura, J. (eds.), 2011, Applied positive psychology. Improving everyday life, health, schools, work and society, Psychology Press, New York.
Dreyer, W.A., 2016, 'Strategiese perspektief op kerkwees, in Praktiese ekklesiologie Kerkwees in die 21ste eeu', HTS Teologiese Studies/Theological Studies 72 (5 suppl. 10), a4380. https://doi.org/10.4102/hts.v72i5.4380

Dreyer, Y., 2011, 'Women's spirituality and feminist theology: A hermeneutic of suspicion applied to "patriarchal marriage", HTS Teologiese Studies/Theological Studies 67(3), Art. \#1104, 5. https://doi.org/10.4102/hts.v67i3.1104

Duckworth, A.L., Steen, T.A. \& Seligman, M.E.P., 2005, 'Positive psychology in clinical practice', Annual Review Clinical Psychology 1, 629-651. https://doi.org/10.1146/ annurev.clinpsy.1.102803.144154

Duffy, R.D., Dik, B.J., Douglass, R.P., England, J.W. \& Velez, B.L., 2018, 'Work as a calling A theoretical model', Journal of Counselling Psychology 65(4), 423-439. https:// doi.org/10.1037/cou0000276

Flynn, A. \& Kramer, S., 2019, Transforming research methods in the social sciences: Case studies from South Africa, NYU Press, viewed 03 September 2019, from https://books.google.co.za/books?hl=en\&lr=\&id=xEaMDwAAQBAJ\&oi=fnd\&pg= PR1\&dq=Flynn,+A.+and+Kramer, +S., +2019.+Transforming+Research+Methods+ $\mathrm{n}+$ the+Social+Sciences:+Case+studies+from+South+Africa.+NYU+Press.\&ots $=\mathrm{pH}$ 5 Rgmuwn 8 \& sig=jQwDAtUMBAp $5167 \mathrm{mgLwNY} 5$ idq 44 \& redir esc $=y \# v=$ onepage\& $q=$ Flynn $\% 2 C \% 20 A . \% 20$ and $\% 20$ Kramer $\% 2 C \% 20 \mathrm{~S} . \% 2 \mathrm{C} \% 20$ 2019.\%20Transforming\%20Research $\% 20$ Methods $\% 20$ in $\% 20$ the $\% 20$ Social $\% 20$ Sciences $\% 3$ A $\% 20$ Case $\% 20$ studies $\% 20$ from $\% 2$ South $\% 2$ Africa. $\% 2$ NYU $\% 20$ Press.\&f=false.

Fourie, M. \& Van Den Berg, J.A., 2007, 'Die ontwikkeling van pastoraal-narratiewe mentorskapbeginsels as effektiewe leerbenadering', Acta Theologica 27(2), 92-104.

Fourie, M.C., 2010, 'Middelloopbaan-ontwikkeling deur spirituele lewenstylafrigting', Doctoral thesis, Dept. of Practical Theology, University of the Free State, Bloemfontein.

Ganzevoort, R.R. \& Roeland, J.H., 2014, 'Lived religion: The praxis of practical theology', International Journal of Practical Theology 18(1), 91-101.

Goss, H.B., Cuddihy, T.F. \& Michaud-Tomson, L., 2010, 'Wellness in higher education: A transformative framework for health related disciplines', Asia-Pacific Journal of Health, Sport and Physical Education 1(2), 29-36. https://doi.org/10.1080/18377 Health, Sport and 122.2010 .9730329

Guest, D.E., 2017, 'Human resource management and employee well-being: Towards a new analytic framework'. Human Resource Management Journal 27(1), 22-38. https://doi.org/10.1111/1748-8583.12139

Huppert, F.A. \& So, T.T., 2011, 'Flourishing across Europe: Application of a new conceptual framework for defining well-being', Social Indicators Research 110(3), 837-861. https://doi.org/10.1007/s11205-011-9966-7

Greenleaf, R.K., 2016, Servant leadership, Greenleaf Center for Servant Leadership, viewed 05 June 2018, from https://www.greenleaf.org/what-is-servant-leadership/.

Janse Van Rensburg, C., Rothmann, S.I. \& Diedericks, E., 2017, 'Person-environment fit, flourishing and intention to leave in universities of technology in South Africa', SA Journal of Industrial Psychology/SA Tydskrif vir Bedryfsielkunde 43(1), 1-10. https://doi.org/10.4102/sajip.v43i0.1422

Jit, R., Sharma, C.S. \& Kawatra, M., 2017, 'Healing a broken spirit: Role of servant leadership', VIKALPA The Journal for Decision Makers 42(2), 80-94. https://doi. org/10.1177/0256090917703754

Kaplan, S., DeShon, R.P. \& Tetrick, L.E., 2017, The bigger picture of employee wellbeing: Its rule for individuals, families and societies, viewed 14 November 2019, from https://www.shrm.org/hr-today/trends-and-forecasting/special-reports-andexpert-views/Documents/2017\%252002_SHRM-SIOP\%2520Employee $\%$ 2520Wellbeing.pdf\&hl=en\&sa=X\&scisig=AAGBfm2nplpX-QbOfLOV97Wh7OVNUB pP_g\&nossl=1\&oi=scholaralrt.

Kirsten, T.G.J.C., Van Der Walt, H.J.L. \& Viljoen, C.T., 2009, 'Health, well-being and wellness: An anthropological eco-systemic approach', Journal of Interdisciplinary Health Sciences 14(1), 1-7. https://doi.org/10.4102/hsag.v14i1.407

Koen, V., Van Eeden, C. \& Rothmann, S., 2012, 'An exploration of families' psychosocial well-being in a South African context', Journal of Psychology in Africa 22(3), 343-358. https://doi.org/10.1080/14330237.2012.10820539

Landman, C., 2007, 'Doing narrative counselling in the context of township spiritualities', DPhil Theology in the Practical Theology, University of South Africa, Pretoria.

Landman, C., 2012, 'Traumatised between culture and religion: Women's stories', HTS Teologiese Studies/Theological Studies 68(2), 6. https://doi.org/10.4102/hts. v68i2.1147

Landman, C., 2015, Personal conversation: URCSA pastors and their experiences on being well, Dept. of Theology, University of South Africa, Pretoria.

Louw, D.J., 2010, “"Habitus" in soul care. Towards "spiritual fortigenetics" (parhesia) in a pastoral anthropology', Act Theologica 30(2), 67-88. https://doi.org/10.4314/ actat.v30i2.67264

Louw, D.J., 2014a, 'Wholeness in spirituality, health and hope care on nurturing the beauty of the human soul', Oral presentation at the spirituality and health care conference: Caring for the life of the whole person on 13-15 November viewed 16 May 2016, from https://www.hospivision.org.za/docs/Louw $\% 20 \mathrm{D} \% 20$ Wholeness $\% 20$ in $\% 20$ Spirituality $\% 2014 \% 20$ November $\% 202015$.pdf.

Louw, D.J., 2014b, 'Philosophical counselling within the realm of a four stage counselling model', Oral presentation at the spirituality and health care conference: Caring for the life of the whole person on 13-15 November, viewed 16 May 2016, from https://www.hospivision.org.za/docs/Louw\%20D\%20Philosophical\%20 https://WWW.hospivision.org.za/docs/Louw $\%$
Counselling $\% 2015 \% 20$ November\%202014.pdf.

Louw, D.J., 2017, 'Pastoral caregiving as life science: Towards an existential hermeneutics of life within the interplay between pastoral healing (cura vitae) and spiritual wholeness', In die Skriflig 51(1), 1-9. https://doi.org/10.4102/ids. v51i1.2183 
Marais, F., 2012, Wat verwag predikante van hulleself? Gemeente dienste network viewed 08 November 2019, from https://view.officeapps.live.com/op/view. aspx?src=https\%3A\%2F\%2Fwww.gemeentes.co.za\%2Fattachments\%2F199 Wat\%2520verwag\%2520 predikante\%2520van\%2520hulleself.doc.

Marques, S.C., Lopez, S.J. \& Mitchell, J., 2013, 'The role of hope, spirituality and religious practice in adolescents' life satisfaction: Longitudinal findings', Journal of Happiness Studies 14, 251-261. https://doi.org/10.1007/s10902012-9329-3

Meyers, J.E. \& Sweeney, T.J., 2007, Wellness in counselling: An overview (ACAPCD-09), American Counselling Association, Alexandria, VA.

Morekwa, O., 2004, 'The interchange, exchange and appropriation of traditional healing, modern medicine and Christian healing in Africa today', MTh dissertation in Partial Fulfilment of a Degree in Systematic Theology, University of South Africa, Pretoria.

Nel, M., 2005, 'Public pastoral leaders: The purpose of theological training', Die Skriflig 39(3), 441-462.

Nel, M., 2009, 'Continuing theological training at the University of Pretoria', Verbum e Ecclesia 30(3), 1-7. https://doi.org/10.4102/ve.v30i3.130

Nel, M., 2017, 'Called and sent to make a difference: Radical missionality', Verbum et Ecclesia 38(1), a1755. https://doi.org/10.4102/ve.v38i1.1755

Nel, M. \& Scholtz, E., 2016, 'Calling, is there anything special about it?' HTS Teologiese Studies/Theological Studies 72(4), 1-7.

Niemandt, C.J.P., 2015, 'Together towards life and mission: A basis for good governance in church and society today', Verbum et Ecclesia 36(1), 1-10. https:// doi.org/10.4102/ve.v36i1.1361

Niemandt, C.J.P., 2016, 'Rediscovery joy in costly and radical discipleship in mission', HTS Theological Studies 72(4), 1-7. https://doi.org/10.4102/hts.v72i4.3831

Nolte, S.P. \& Dreyer, Y., 2010, 'The paradox of being wounded healer: Henri J.M. Nouwen's contribution to pastoral theology', HTS Theological Studies 66(2), 1-8. https://doi.org/10.4102/hts.v66i2.861

Northcutt, N. \& McCoy, D., 2004, Interactive qualitative analysis. A systems method for qualitative research, Sage, London.

Osmer, R.R., 2008, Practical theology, an introduction, Eerdmans, Grand Rapids, MI.

Peterson, C., 2006, Special seminar in psychology: Positive psychology, viewed n.d., from https://ppc.sas.upenn.edu/sites/ppc.sas.upenn.edu/files/ppsyllabus2006peterson. pdf.

Plaatjies Van Huffel, M.A., 2017, 'From conciliar ecumenism to transformative receptive ecumenism', HTS Teologiese Studies/Theological Studies 73(3), a4353. https://doi.org/10.4102/hts.v73i3.4353

Robertson, C.A., 2015, 'Leadership development for technical and vocational education and training college leaders in South Africa: A post-graduate curriculum framework', PhD dissertation, Dept. of Curriculum Studies, Faculty of Education Stellenbosch University, Stellenbosch.

Rothmann, S., 2013, 'From happiness to flourishing at work: A South African perspective', in M.P. Wissing (ed.), Well-being research in South Africa: Crosscultural advancements in positive psychology, vol. 4, pp. 123-151, Springer, Dordrecht, viewed 14 November 2019 from https://doi.org/10.1007/978-94-0076368-5_7.
Rudolph, E.C., 2019, 'A coaching model to care for the well-being of pastors: A multidisciplinary perspective', Doctoral dissertation, University of South Africa,
Pretoria, viewed 14 November 2019, from https://uir.unisa.ac.za/handle/10500/ 25671.

Rudolph, E.C. \& Barnard, A., 2015, 'A voice in the dirt: African pastors on being well', poster presentation at the European Conference of Psychology (ECP), Milan, Italy, 7-10 July.

Schoeman, K., 2012, 'Die predikant se lewe en werksomgewing', Kruisgewys 6-8 viewed 14 November 2019, from https://www.gemeentes.co.za/kruisgewys/ kruisgewys-julie-2012/201-die-predikant-se-lewe-en-werksomgewing.

Schreuders-Van Den Bergh, R., 2013, 'The facilitative role of cultural intelligence in the adjustment and career development of self-initiated expatriate women', Unpublished PhD thesis, Faculty of Economic and Management Science, University of Pretoria, Pretoria.

Seligman, M.E.P., 2011, Flourish, a visionary new understanding of happiness and wellbeing, Free Press, New York.

Seligman, M.E.P., Parks, A.C. \& Steen, T., 2004, 'A balanced psychology and a full life', Philosophical Transactions of the Royal Society 359, 1379-1381. https://doi. org/10.1098/rstb.2004.1513

Sixth General Synod of URCSA, 2012, Minutes: The uniting reformed church in South Africa strategic plan 2010-2016, viewed from https://www.vgksa.org.za/ documents/Acta\%20Synod\%202012.pdf.

Travis, J.W., 2004, Illness-wellness continuum, viewed 14 November 2019, from https://www.wellpeople.com/What_Is_Wellness.aspx.

Travis, J.W. \& Callander, M.G. 2013. Beyond Ordinary Wellness: Full-Spectrum Wellness, viewed 14 November 2019, from http://www.connectedandthriving. org/documents/Beyond-Ordinary-Wellness-NWC.pdf.

Travis, J.W. \& Ryan, R.S., 2004, The wellness workbook: How to achieve enduring health and vitality, 3rd edn., Random House Digital, Inc., New York, USA, viewed 20 March 2015, from https://www.amazon.com/gp/product/1587612135?ie=UT F8\&tag=thewellOb-20\&linkCode $=$ as $2 \&$ camp $=1789 \&$ creative $=9325 \&$ creativeAS IN $=1587612135$

Tshaka, R.S., 2014, 'On being African and Reformed? Towards an African Reformed theology enthused by an interlocution of those on the margins of society', HTS Teologiese Studies/ Theological Studies 70(1), Art. \#2070, 7 pages. https://doi. org/10.4102/hts.v70i1.2070

Tomic, W., Tomic, D.M. \& Evers, W.J.G., 2004, 'A question of burnout among Reformed Church ministers in the Netherlands', Mental Health Religion \& Culture 7(3), 225-247. https://doi.org/10.1080/13674670310001602472

Wessels, F. \& Müller, J.C., 2013, 'Spirituality in narratives of meaning', HTS Teologiese Studies/Theological Studies 69(2), Art. \#1187, 7 pages. https://doi.org/10.4102/ hts.v69i2.1187

Wong, P.T.P., 2004, 'Compassionate and spiritual care: A vision of positive holistic medicine', Keynote address at the conference on holistic healthcare for the medical, religious and academic, Nethersole Institute of Continuing Holistic Health Education, Hong Kong, 11 June.

Wong, P.T.P., 2011, 'Positive psychology 2.0: Towards a balanced interactive model of the good life', Canadian Psychology 52(2), 69-81. https://doi.org/10.1037/ a0022511 